\title{
生体認証における性能評価への取組み
}

\section{Performance Evaluation Efforts and Standardization of Biometric Systems}

溝口正典 Masanori MIZOGUCHI

アブストラクト バイオメトリクスは生体認証や身体認証などと訳されている. 本稿ではその精度評価方法の開発の歴史, 特に米国国立標準技術研究所 (NIST) 等による性能評価試験, 米国規格協会 (ANSI) 等によるデータフォーマットの米 国標準化の動きから, ISO/IEC JTC 1 SC37で開発された国際標準化までの, バイオメトリクス精度評価関連の標準 化活動を概観する. 精度評価というと,ベンチマークテストのような試験を想像される方も多いと思う. しかし, フレー ムワークとして開発された精度評価方法の国際標準ISO/IEC 19795 シリーズに書かれている内容はそのようなもの ではない.ここではSC37で既開発あるいは開発中のIS (International Standard)やTR (Technical Report)に どのようなものがあるか紹介し, トピックとして反復性と再現性, 偏りのないデータ収集のあり方, サンプルデータ セットからの統計的性能推定などを取り上げて,それらの重要性を指摘したい. また, ル一ツの異なる専門用語定義や， 翻訳の難しさなどについても触れる. 最後に今後の研究が期待される未解決な課題について述べる.

キーワード バイオメトリクス, 精度評価, 性能評価, 国際標準, 専門用語

Abstract Biometrics is translated into Japanese as "Seitai-Ninshou" or "Shintai-Ninshou" . This article gives an overview of the history of developments in the performance evaluation methodology for biometrics. It starts with a description of standardization activities for interoperable data formats and performance evaluation testing technologies developed by NIST and ANSI in USA, followed by international standardization activities related to biometric performance evaluation described in ISO/ IEC JTC 1 SC37. Although the term "performance evaluation" may remind readers of benchmark tests, the contents of the developed standard provide a framework for biometric system performance evaluation rather than test specifications for benchmarks. Published international standards and technical reports and those under development in SC37 are briefly referred to. Then several topics such as repeatability and reproducibility, a data sampling method without biasing, and the stochastic estimation of performance metrics using a sample data set are outlined as important issues. Confusion and misunderstanding regarding translated Japanese technical terms caused by various domain roots are mentioned. Finally, unsolved problems expected to be researched in future will be discussed.

Key words Biometrics, accuracy, performance evaluation, international standardization, technical terms

\section{1. はじめに}

生体認証は最近ではスマートフォンの指紋認証や顔認証な ぞで，日常的に身近なものになってきている。これは身体の 部位パターンや動作パターンについて, 登録済みのパターン 情報と比較して同一人物であるか否かを正しく認識する機 能・性能が実現できたからであるが，その正しさの度合いを どのように評価してきたのか, というのが本稿のテーマであ る.

コンピュータによる自動検索や自動照合という意味でのバ

溝口正典 正員 日本電気株式会社第二官公ソリューション事業部

E-mail m-mizoguchi@cd.jp.nec.com

Masanori MIZOGUCHI, Member (2nd Government and Public Solutions Division NEC Corporation, Tokyo, 108-8001 Japan).

電子情報通信学会 基礎・境界ソサイエティ

Fundamentals Review Vol.10 No.2 pp.137-142 2016年10月

C)電子情報通信学会 2016
イオメトリクスは指紋照合から始まった. 10 本の指紋を押捺 した 10 指カードのデータベースから, 被疑者が偽名を使っ ていても再犯者かどうかを調べたり，犯行現場に残された遺 留指紋との一致性から被疑者手配を行ったり, 裁判での証拠 書類作成をしたりする応用である。このような目的で，ある 指紋画像がデータベースに登録された指紋画像と同一指によ るものであることを検索する機能が自動指紋識別システム (AFIS: Automated Fingerprint Identification System)の役割であ る. AFIS はその後, 職員の入退場での本人確認, 業務システ ム利用でのユーザ本人確認等, 様々なシステムで事前に登録 申請した人物であることを証明し, 登録者の権利を行使でき るようすること, いわゆる身分証明や本人証明の応用で発展 してきた。

セキュリティに関わるため, その判定精度は一定以上に高

いことが示される必要がある。このため, 精度評価の方法が 
検討され, ノウハウが蓄積され, 国際標準化がなされている. なお, ISO/IECの国際標準化文書には大きく2 種類あり, 要求 項目 (Requirement) に対する適合性 (Conformance) を求めるIS (International Standard) と, 技術としてはまだ未成熟であり利 用時の参考になる技術事項をまとめたTR (Technical Report) とがある。なお TRは規格番号の前にTRが付いている.

本稿では, まずバイオメトリクス精度評価の歴史的な背景 と当時の評価方法を紹介し, その後, 様々に開発されてきて いる国際標準化文書について簡単に一覧する。更に筆者がバ イオメトリクス精度評価に打いて重要と考える概念や事項に ついてトピック的に幾つか取り上げて解説する。最後に今後 の研究課題となりそうな事項について紹介する.

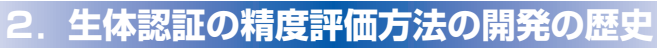

\section{1 米国NIST等による性能評価試験}

米国では 1970 年代に自動指紋識別システムAFIS が開発さ れ，導入促進の予算化措置などもあって各州警察に導入され ていった ${ }^{(1)}$. 米国の警察制度は地方自治によるボトムアップ 的なのが特徴である. 町や大学レベルでの保安官から, 郡警 察, 市警察, 州警察, 連邦レベルのFBIへと権限が広域にな る階層的な構成になっており, 調達や仕様決めも自治が原則 なので必ずしも統一されていなかった。また, 購入者は他機 関よりも良いものを導入したいと考えるのは自然な要求であ り，競争が促進されたとも言える。日本のトップダウン的な 基本仕様で導入する流れとはかなり異なっている。したがっ て米国では性能評価も各調達者がベンチマークテストを個々 に実施するやり方となる。しかしそれでは効率的とは言い難 く，実施された複数のテスト結果の比較が難しいことから評 価用の共通データベースや, 要求精度性能を表現するための 共通的な性能指標の必要性が認められていった。また隣の州 のAFISに照会をかけるためには指紋画像データのハンドリ ングを共通化して相互運用を可能とするようなデータフォー マットの共通仕様, 画像データの圧縮伸長アルゴリズムの共 通化なども必要であり，更には照合処理に適しているかを画 像品質で判断し, 照合結果の信頼性を考慮するために, 画像 品質尺度や照合に用いる標準的な特徴量表現形式など, 様々 な相互運用性を高める標準化活動へと進んでいった。

その中で主導的な役割を果たしたのが, FBI-CJIS (Criminal Justice Information Service Division) や NIST-ITL (National Institute of Standards and Technology-Image Technology Laboratory) で ある.ここで標準化されたものとしては, 指紋画像品質を 確保するための指紋スキャナやプリンタの規格IQS (Image Quality Specification), 画像圧縮伸長の規格WSQ (Wavelet Scalar Quantization) などがある。これらの規格によって指紋 画像の解像度, 空間周波数特性, 最大画像サイズ, 濃淡レべ 儿数とその分布条件, ひずみ許容度, 杂隹音許容度, 圧縮ひず みの許容度などの品質レベルが確保されている。一方, NIST は指紋照合アルゴリズムの精度性能, 速度性能を調べるPFT
(Proprietary Fingerprint Template) Evaluationをスタートさせ た. PFTはベンダ独自の特徴量形式を用いることが許されて おり，指紋画像でどこまで自動照合できるのかチャレンジす ることで, その時点での限界能力を調べるものであった。 こ れ以降, 各ベンダによる照合精度向上の研究開発競争が始 まった。なお，PFTは1指の押捺指紋同士の照合処理を基本 とした 1 対 1 の照合性能評価であり, 本人確認や押捺指紋同 士の照合性能を調べるもので，遺留指紋は対象ではない．

NISTではその後, 標準化した指紋特徴量形式を用いた精度 評価MINEXや，4指を同時に押捺した画像から個々の指紋を 分離する精度評価SlapSeg, 遺留指紋の照合精度評価ELFTな ど, テストの種類を増やしてきている.

\section{2 米国ANSIなどによる標準化}

ANSI (American National Standards Institute) は米国国家標準 化の組織であって, NISTにより開発された指紋画像データ形 式がANSI/NIST形式として米国警察機関の標準データ形式に なっている。これは米国から Interpolにも提案されて採用さ れ警察関係では事実上の国際標準規格になっている。

一方，911テロ事件以降，米国では主に入国管理に指紋照 合を用いて好ましくない人物の指紋であるか否かを識別す るUS-VISITを実現することになり，そのシステム設計を行 うためにそれまでにない大規模な指紋照合の性能評価試験 FpVTE2003をNIST 主導で実施した。またICAO（国際民間航 空機関) ではICチップ入りパスポートに格納するバイオメト リックデータとして, 顔画像を必須とし, 指紋画像, 虹彩画 像をオプションとすることが決まった。これにより，指紋， 顔, 虹彩の 3 モダリティに関して, 米国やヨーロッパなどで 実証実験やパスポート保持者の本人確認に対する評価試験が いろいろと実施されるようになっていった。また，そのよう な動きと並行して, ISO/IECではJTC1にバイオメトリクスを 扱うSC37を2002年に新設し, 必要な国際標準を開発するこ ととし, その中で精度評価法と報告を取り扱うWG5 が設置 され，精度評価法の国際標準化が本格的にスタートした。

\subsection{ISO/IEC JTC1 SC37で開発された国際標準 における精度評価関連事項}

SC37のバイオメトリクス精度性能評価はWG5で開発が行 われてきた。バイオメトリクスの性能評価については英国の Tony Mansfield と米国の Jim Wayman らが2000年に作成した "Best Practice in Testing and Reporting Performance of Biometric Devices”という文書があり, 略称Best Practice として知られ ていた. Jim Wayman (サンノゼ大学) は統計的な精度評価法 に関する論文を多数出しており, Tony Mansfield ら英国の研 究グループと一緒に評価技術のガイドラインを作ったのであ る. Best Practiceは2002年に改訂されてVer.2になっているが, これがSC37での性能評価試験のフレームワークを記載した, ISO/IEC 19795-1 Biometric Performance Testing and Reporting - 
Part1 : Principles and Frameworkのべース文書になった ${ }^{(2),(3)}$. 19795-1ではバイオメトリクスの性能評価で使われる様々 な概念や評価尺度が定義されている．特に基本的な性能評 価尺度として, FMR (False Match Rate), FNMR (False NonMatch Rate), FAR (False Accept Rate), FRR (False Reject Rate), FTE (Failure to Enroll Rate), FTA (Failure to Acquire Rate), ROC Curve (Receiver Operating Characteristic Curve), CMC Curve (Cumulative Match Characteristic Curve) などのい ろいろな共通性能指標への認識ができたと言える。時たま AcceptではなくAcceptance, またRejectではなくRejectionで はないかと聞かれることがあるが，SC37WG5では英国人 委員を主体にした議論でAccept, Rejectと定義されている. ROC は雑音のあるレーダ信号から敵機の存在を検出するとき の誤り評価法に由来しているとのことである，ROCの縦軸と 横軸をどうとるかについては様々な論文で統一されていない 面もあったが，19795-1ではROCを変形して，縦軸と横軸の 双方が誤り率となるようなDET Curve (Detection Error Tradeoff Curve）が定義されており, false positives on the $\mathrm{x}$-axis and false negatives on the y-axis と定められている。これにより複 数の報告書の精度評価結果について DET Curve 間の比較参照 を容易としている。

精度評価はこれまで主としてSC37WG5で審議してきたが， 最近は他のWGとの Jointで開発される傾向がある。例えば 人工偽造物の提示攻撃を検知する 30107 シリーズに関しては データフォーマットを扱うWG3 と開発したり，ビデオ監視 システムのデザインや仕様と性能評価に関する 30137 シリー ズに関しては技術実装を扱うWG4 と開発したりという具合 である。

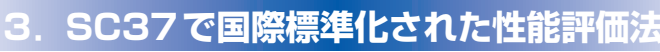

\section{1 性能評価のフレームワーク}

19795-1 には性能評価のフレームワークが記載されており， 具体的なテスト仕様そのものが書かれているわけではない. 特定のテスト仕様ではなく，テストを実施する設計者や責任 者が考慮すべき事柄が書かれているのである.

例えば，19795-1の第6条の評価計画や第7条のデータ収集 に書かれている事項は，試験を設計する上で重要であるが， その文章は全体を読まないと理解しにくい面もある.

実際の事例で少し説明しょう。6.3 条のシステムに関する情 報の判定では「試験責任者は適切なデータ収集手順を計画す るために, 試験するシステム (群)に関する次の情報を判定し なければならない.」とされており，6.3条で挙げられている 項目の一つの例には，「e：試験のためにシステムの修正が必 要となるか。必要となる修正はシステムの性能特性を変えて しまうか.」と書かれている。恐らく上記を読んでも，この条 文の意図や適用場面がすぐには分からないのではないだろう か.

上記項目 $\mathrm{e}$ の具体的事例として考えられる場面とは以下の
ようなものであろう，試験を設計する責任者が，他人許容率 と本人拒否率のトレードオフを表現したDETカーブを提出す ることを義務付けたとしょう。しかしながら, 評価対象製品 が固定しきい值の製品であったなら DETカーブを描けない, そこで，しきい值を可変にした修正版の提出を求めることに なるが，その修正版で性能特性が変わらないことをべンダは 示す必要がある，というように理解すべきなのである.

このように，19795-1では試験仕様そのものではなく，試 験仕様を設計する際に注意すべき事項が書かれている。この ことを記憶にとどめて頂きたい.

19795-1 に沿って設計した個々の性能評価試験は設計者に よって異なっている。19795-1に準拠した試験だからと言っ て，その結果を同列に比較することはできないのである.

\section{2 既開発及び開発中のIS, TR}

SC37WG5 で開発されたIS，TR と現在開発中のものについ て表1〜3にまとめておく(2), (4).

ここでは個々の標準の詳細まで紹介しない。学術論文にお ける照合アルゴリズムの評価に最も親和性のあるのは「技術 試験」（Technology Test）である。その精度評価に関する用語 や概念については，19795-1や19795-2，その日本語訳である JIS X8101-1 P8101-2を参照して頂ければ幸いである ${ }^{(3)}$. なお これらのほかにも, 本稿執筆時点での新規提案としてモバイ ルシステムの性能評価方法など幾つかのテーマが挙がってき ている.

\begin{tabular}{|l|l|}
\multicolumn{2}{c}{ 表 $1 \quad$ 発行済み19795 シリーズ } \\
\hline $19795-1$ & 性能評価フレームワーク \\
\hline $19795-2$ & 技術評価とシナリオ評価 \\
\hline TR19795-3 & モダリティごとに特有な事項 \\
\hline $19795-4$ & 相互運用性の試験方法 \\
\hline $19795-5$ & $\begin{array}{l}\text { アクセスコントロールシナリオ評価に打ける } \\
\text { グレーディングスキーム }\end{array}$ \\
\hline $19795-6$ & 運用評価のテスト方法論 \\
\hline $19795-7$ & オンカード型比較アルゴリズムの試験 \\
\hline $19795-2$ 追補1 & マルチモーダル実装の試験 \\
\hline
\end{tabular}

表2 その他の発行済み性能評価関連標準

\begin{tabular}{|l|l|}
\hline 29120 & 機械可読試験データ \\
\hline TR29156 & $\begin{array}{l}\text { セキュリティとユーザビリティの性能要求を } \\
\text { 示すガイダンス }\end{array}$ \\
\hline TR29189 & イグザミナがアシストするシステムの評価 \\
\hline 29197 & 環境の影響についての評価方法 \\
\hline TR29198 & 指紋データベースの難易度の特性と計測 \\
\hline
\end{tabular}

表 3 現在開発中の性能評価関連標準

\begin{tabular}{|l|l|}
\hline $30107-3$ & 提示攻撃検知の性能評価 \\
\hline 30136 & テンプレート保護方式の性能試験 \\
\hline $30137-2$ & $\begin{array}{l}\text { ビデオ監視システムでの生体認証利用の性能 } \\
\text { 評価と報告 }\end{array}$ \\
\hline
\end{tabular}




\section{3 計測の信頼性}

計測における信頼性は重要である。「不確かさの求め方」 (JAB NOTE2) (5)によれば，規格に沿った測定だけでは信用 されないことが多くなり始めており，「校正機関及び試験所 の能力に関する一般要求事項」（最新はISO/IEC 17025：2005, JIS Q17025：2005）に従った試験所認定の流れがあるとされ ている。そして，19795-1では17025が Normative Referenceと なっており，9条の記録管理で 17025 に従うことが要求されて いる.

単なる試験測定值だけではなく，測定方法や測定データと その結果を詳細に報告することで，測定值の信頼性を検証で きるように記録することは，今後国際的に受け入れられるた めにも重要であろう.

信頼性評価方法には様々な方法があり，バイオメトリク ス分野でどのように不確かさを报っていくかは今後の課題 である。「不確かさ」に関連する文書として，国際度量衡委 員会 (CIPM) が提案した, 国際文書「Guide to the expression of Uncertainty in Measurement (略称GUM)」が1993年に発行され ており，翻訳も1996年に日本規格協会から「計測における不 確かさの表現のガイド」として刊行されている( ${ }^{(6)}$.この中に 「バジェットシート」という表があるが，これは標準不確かさ， 分布形状, 補正係数など, 不確かさの要因を効率的な手法で 表現するものである。また真の值の存在する範囲を示す推定 值としての不確かさを，使用した測定法や校正法の信頼性の 連鎖の道筋から明確にするようにしている。

このほかにエラーバジェットという概念もある。これは， システムで許容する誤りを項目別に分けたものである。仕様 を満たすよう, 各プロセスの誤り発生率の振り分けを行うも ので，計測プロセスとその摇らぎ発生メカニズムが統計モデ ルとして把握されているときに利用することができる。例え ば，照合処理を高速だが粗い絞り込みのプロセスと，低速だ が高精度な詳細照合プロセスの2段階で行うときに，それぞ れのプロセスの許容誤り配分設定への適用がある.

最近の自動車の燃費計測詐称のニュースで計測值の信頼性 の重要性が認知されるようになったと思われる，あるメ一カ は決められた測定法では摇らぎが大きいので，計測プロセス を複数のプロセスの合成としてモデル化し，個別プロセスの 計測結果から推計していたと公表したことも記憶に新しいと ころである。いずれにしても何らかの測定の妥当性や統計的 な信頼性に関する考え方を示して，信頼性を伴った測定結果 を提示していくことが望ましい

\section{4 反復性と再現性}

統計的な扱いに関しては，何回測定しても同じ結果が出る 反復性 (Repeatability) と，誰がどこでやっても同じ装置，同 じデータであれば同じ結果が出る再現性 (Reproducibility) が, 計測に打ける基本的な要求事項である。19795-1にはこの R\&R (Repeatability and Reproducibility) を保証するための必須
要件が書かれていると見るべきだと考えている，ただし，対 象のアルゴリズムや製品によっては非該当となる事項もあり 得る.

更に19795-1には記載されていないが，試験を設計する際 には，不正に対する考慮も必要である。測定中にデータ属性 を利用されたりしないこと, 結果を改ざんされないことが, 測定システムの設計において要求される。例えば，評価用の データファイルでは, ファイル名やヘッダ情報に, 採取日付, スキャナID, GPS データなどが含まれてはならない。また， 画像品質の扱いについては事前にルールを定めておくこと, 特に低品質データを安易に対象外とすることで，一見すると 高精度な結果を出すようなことがあってはならない. 試験責 任者はこれらを考慮して試験を設計・計画し，試験方法や提 出物の仕様書として提示すべきである.

\section{5 偏りのないデータ収集のあり方}

バイオメトリクスで扱うデータは個々の生きている人間か ら採取したものであり，精度評価を行う場合には統計的な摇 らぎが複雑に影響していると考えられる。例えば，同一人物 であっても，採取装置に対する利用者の相対位置の違い，体 の部位を提示する際の姿勢や動作速度の影響，体調や成長/ 老化などの生体自体の変化, 気温などの環境要因変動による センサ特性の変化, 同様に環境要因変動による血流や発汗な どの生理的な変動などが起こり得る。

各種変動に加えて, 利用者の集団的な性質の違いも存在し ており，それらの影響を受けないような試験にすることが望 ましい，集団的な性質については，例えば皮膚や虹彩の色な ど人種的な違いや, 年齢, 性別などの層として捉えることが できる場合もある．皮膚の乾燥や荒れなどの遺伝的，体質的， 職業的な要因の影響も許容した測定とするべきである.

人口統計に従ったサンプリングを行うことで，「平均」のよ うな代表的指標となる性能值を得ることができるが，一般的 にはそのシステムの主要なユーザの属性を想定した測定をす ることが多いと思われる。

実際に測定用のデータセットを作成する際には，上記の項 目を考慮して設計するわけだが，画像や音声などの信号では 以下のような具体的な問題が生じることがある.

（1）照明：顔や虹彩の採取の場合，非接触で反射光を用い ることから，眼鏡のレンズや瞳の中にキラキラしたス ポット反射が出る場合がある.

(2) 顔の向きは正確に制御しにくい.

（3）環境照明や騒音が重畳された信号になる。

これらの制御困難な要因は評価時と運用時で異なる可能性 があり，運用精度の推定はより難しくなる.

$R \& R$ の面からは統計的に信頼性の高い結果が得られれば良 いと言える。そのためにはサンプリングの妥当性が重要にな る。19795-1では第7条でデータ収集に扎いて考慮すべき事項 が書かれている．例えば，「間違った入力をする被験者やオ ペレータを考慮すべきである」と書かれている. 採取したデー 
タの品質は性能に大きく影響するので, 品質レベルを保つた めの注意事項や採取方法に関しても記載されている．試験責 任者はそれらを考慮した評価試験を計画しなければならない としている.

性別，年歯命，画像品質などについて対象を複数のクラスに 分類しておき，クラスごとに性能を分析し，実運用時の性能 をクラス別の重み付けで高精度推定することも考えられる. 更に例外処理の導入も考慮する必要があるが，その適用ルー ルは試験実施前に明確にしておくべきである。

\section{6 サンプルデータセットからの統計的性能推定}

一体どのくらいのサンプル数で評価を行えばよいのだろう か？これは実験結果を報告する際の信頼性の問題である．製 品のカタログ精度值も, 統計的に有効なデータ規模で評価さ れているのかを含めて判断しなければならない.19795-1の 附属書 B「試験規模及び不確実性」には，“Rule of 3”,「3の法 則」が書かれている．䛊り率が $p$ 以下であることを信頼水準 95\%で示すには，誤り発生の期待值が 3 回になる規模の試験， すなわち $3 / p$ 回規模の試験において, 誤りが 1 回も起きなけれ ばよい, というものである.

誤り率の計算方法としては，量産製品の製造工程の品質管 理で一般的に使われる 2 項分布モデルで, $N$ 回中 $k$ 回誤りが起 きたときの誤り発生率で計算することがある。統計パッケー ジソフトであれば，簡単に計算することができ，例えば $R$ を 使った場合ならば， $N=300 ， k=1$ で，信頼水準 $95 \%$ の誤り率 の信頼区間は $[0,0.0157]$ と簡単に分かる (図 1 参照)。なおこ こで統計モデルとして2 項分布でモデル化することが適切か どうかは個別に議論すべき話である。いずれにしても大まか な近似あるいは目安として, この3の法則を用いることで, 測定結果の信頼性レベルがある程度保証されると考えてよい のではないだろうか。

\section{7 ルーツの異なる専門用語}

用語に関してルーツが異なる複数の用語がある場合，どの 用語を選択するべきかが面倒な問題となる。例えば，自動指 紋識別 (AFIS) の分野では，登録側DBのデータをfile，検索

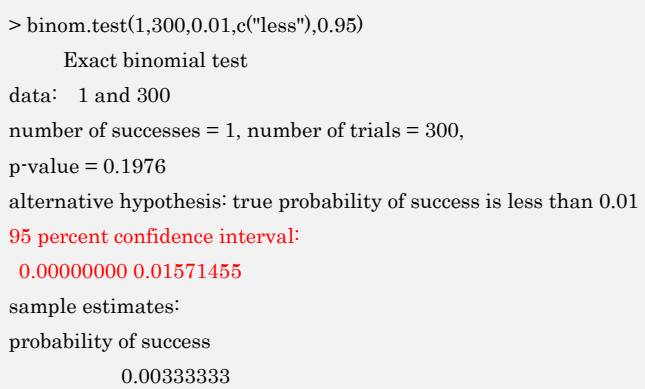

図 1 Rによる信頼区間の計算事例

が起きたときの 95\%信頼区間)。
側を search と呼んでいた。顔照合や話者照合などの他モダリ ティでは，例えばDB側を gallery，検索側にquery あるいは probeなどが使われたりする。登録側を referenceとし，特徴抽 出して特徴量になったデータを template とすることもあった。 19795-1の開発段階当時は, 出入国管理システム等の調達仕 様の記述に使えるよう発行を急ぐ必要があったため，登録側 のデータを reference と呼ぶことだけはすぐ決まったが, 検索 を行う側の呼び方が当初はなかった。しかしそれでは分かり にくく対称性もないので, 比較を行う側を probe と呼ぶこと に決まった経緯がある。

照合結果に関しては，AFISでは多数の登録データとの 1 対 多の検索を行って, 見つかった場合はhit, 見つからなかった 場合はno-hitとしていた。一般のバイオメトリックシステム では 1 対 1 の比較結果を扱うことが多く, match と non-match を使うことが一般的である。

“match”の誤り率については, SC37ではfalse-match-rate (FMR) が採用されている。そして，“match”は一致したとい う結果を示す名詞用法だけに限定している。したがって，比 較処理の表現として Matching という用語がかなり使われてい るが，19795では比較処理自体に“matching”を使うことを避 け “comparison”とし，その比較結果が matchかnon-matchのど ちらかであると使い分けることにした。このような語法は論 文執筆でも有用なのではないかと思われる.

\section{8 標準化における訳語の難しさ}

バイオメトリクスの性能評価ではFAR, FRRが広く使わ れている. FARを他人受入率, FRRを本人拒否率と訳すこ とが多いのだが，実はこの翻訳は適切とは言えない，動詞の accept や rejectは目的語をとるはずだが，それは何になるのだ ろうか. 実は“Biometric claim”なのである. Claimとは例え ば，「私は登録してある溝口正典です」という認証要求のこと であり，それを受理するかどうかが accept/rejectである。した がって，「私はまだ登録されていません」というネガティブな Claimの場合には，登録済みの referenceのどれにも matchしな かったときにacceptされるのである。これは通常の本人認証 の場合における, match/non-match と accept/rejectの対応関係 とは逆になることに注意が必要である。FARを他人受入率と するのは前後関係からポジティブな Claim を想定したときの 意訳になっていると理解する必要がある.

このほか, 国際標準化ではフランス語訳が作成されたり するが，ものによっては各国で自国語に訳したものを発行 することがある。しかし, 元の英単語に対応する語彙が 1 対 1 に存在するとは限らないことがある。例えばMatchについ て，19795-1の日本語訳であるJIS X8101-1では「合致」と訳し ている。しかし，「一致」を使った論文や文献も多いのでは ないかとみている。それぞれの単語の意味を考えてみると， reference データと probeデータが全く等しいという意味での 「一致」はほとんど起きないことから,「合致」の方が適切と言 えなくもないと打分かり頂けるのではないだろうか. 


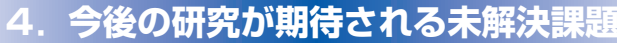

バイオメトリック製品の性能評価をする場合, 同じデータ セットを使わない限り，正確な製品性能の比較はできない. データベース (DB) の異なる性能評価結果を比較するために， DB ごとに本人照合の難易度を考慮した補正をすることがで きるのではないかという考え方も出ている．例えばDBに低 品質データが多かったならば，そのDBでの照合率は低くな るはずである。そこで補正するための照合性能と比例関係に あるような DB 難易度の導入が提案された。しかし，その計 算はなかなか難しく実用化に至っていない。すなわち異なる データベースによる測定結果の比較の方法はまだ解決されて いない問題である。

個人情報保護のためデータの複製に制約があり，評価機関 間で共通評価データを持つことは段々と難しくなってきた. また情報漏えいリスクなどもあり，大量の個人情報を収集す ること自体が問題にされることもある。このようにバイオメ トリクスの性能評価そのものが実施しにくくなってきている 面がある。

一方，研究が進んで䛊り発生率が非常に小さくなり高精度 化が進み，3の法則からその評価試験に必要なデータ規模は 非常に大きくなってきている。このため評価コストが膨大に なってきている，規模の小さいベンダにとっては，そのコス 卜負担は厳しい関門になっていると考えられる。より少ない データで信頼性の高い性能測定ができる方法論，あるいは人 工的なデータを用いることで大規模 DB を使用した時と同等 な評価ができればうれしいところである。

偽造指紋やマスク（お面）を用いた提示攻撃検知 (Presentation Attack Detection: PAD) の性能評価では, 攻撃の スキルや知識を評価にどう反映させるかが課題である。新た な攻撃手法が次々と出てくるが，SNSで攻撃方法が非専門家 にも容易に拡散する可能性が高くなってきている。このため PADの評価で，どのような攻撃を用いて評価を実施するのが 妥当なのかは難しい問題となってきた。

また，照合精度やPADに関して，製品のCC認証を行う動 きも出てきている。しかし，入力データのバリエーションが どの程度の広がりで存在するのか，それをどこまで性能試 験での評価に反映させるのが妥当なのかはよく見えていな い. 評価対象が人間の集合であれば何とかイメージできるが， PAD を含む評価において人工物をどこまで用意すればよいの かは難しい問題である.

\section{5. おわりに}

バイオメトリック認証システムへの攻撃方法は日々進化し ている．本当に再現性のある攻撃を実施することは容易では なく, どのように性能評価を行うべきなのかは難しい問題で ある。

採取データの画像品質は性能に大きな影響を及ぼすもので あり，品質值から照合性能を予測したいところだが，残念な
がら指紋の画像品質の研究は進んでいるものの, 他のモダリ ティでは優れた品質指標がまだ無い，顔照合では顔の角度， 顔の重なり，マスクによる隠蔽で一部分しか見えないことも ある。これを品質值で扱うこともできるかもしれないが，ど の程度見えていたらどのくらい照合できるかという，システ ム運用者の期待にあった精度評価実現のアイデアはまだ出て いない.

動画像処理や監視画像などでの性能測定では, 秒当り数十 フレームの画像や多数のカメラ間で被写体の対応を取った膨 大な規模の正解值 (信頼度付が望ましい)が必要であり，そ れを効率良く与える方法への期待がある。正解值は“Ground Truth”と呼ばれ, 人手による付与や目視確認をいかに軽減す るか，つまり Ground Truthの生成工程をいかに効率化できる かが, 今後の高度な性能評価標準で求められていくと思われ る。

以上, 精度評価分野で解決が期待される事項について筆者 の考えを御紹介した．今後の研究テーマ設定などで参考にな れば幸いである。

\section{文献}

（1）指紋認証技術バイオメトリクス・セキュリティ，星野幸夫 (監修), 画像電子学会, ISBN 4-501-32480-5

（2）SC37 で成立済みのPJ 一覧. http://www.iso.org/iso/iso_catalogue/ catalogue_tc/home/store/catalogue_tc/home/store/catalogue_tc/ catalogue_tc_browse.htm?commid=313770\&published=on

（3） JIS X8101-1. 日本規格協会で販売している。しかし，閲覽だ けであれば日本工業標準調査会の下記ぺージで. http://www. jisc.go.jp/app/JPS/JPSO0020.html, 「X8101-1」をキーインして 検索して閲覧が可能である。印刷はできない.

（4）SC37で開発中の PJ 一覧. http://www.iso.org/iso/iso_catalogue/ catalogue_tc/home/store/catalogue_tc/home/store/catalogue_tc/ home/store/catalogue_tc/catalogue_tc_browse.htm?commid=31377 0\&development $=$ on

（5）JAB NOTE $2\lceil$ 不確かさの求め方」(機械・物理試験分野)，(財) 日本適合性認定協会, 2000.

（6）田中秀幸, 不確かさ評価について, https://www.nmij.jp/ $\sim$ nmijclub/hoteikeiryo/docimgs/tanaka_20081001.pdf

(BioX研究会提案, 平成 28 年 8 月 8 日受付)

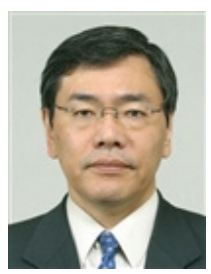

溝口正典 (正員)

1980 東工大大学院総合理工学研究科修士課程了 (電 子システム専攻)。同年日本電気株式会社入社，中央 研究所にて高速画像処理プロセッサ, 人工ニューラル ネット処理プロセッサ, 指紋分類方式, 掌紋照合方式, 道路画像監視システムなどの研究開発に従事.1999 に事業部門に異動し, 指紋照合応用システム, 静脈照 合応用システムなどの製品・システムの研究開発に従 事しながら, 生体認証関連の国際標準開発の活動にも 参画. 現在, 第二官公ソリューション事業部, 主席技 術主幹。 